\title{
Development of the chromatographic medium for the affinity isolation of the recombinant hIFN- $\beta 1 b$ based on immobilized single-chain antibodies
}

\author{
Ia. O. Pokholenko, ${ }^{1,2}$, O. B. Gorbatiuk ${ }^{1,2}$, O. V. Okunev ${ }^{1,2}$, D. M. Irodov ${ }^{1,2}$, \\ M. I. Degtiarova 1 , O. G. Palyvoda' ${ }^{1,2}$, V. A. Kordium ${ }^{1,2}$ \\ ${ }^{1}$ Institute of Molecular Biology and Genetics, NAS of Ukraine \\ 150, Akademika Zabolotnoho Str., Kyiv, Ukraine, 03680 \\ ${ }^{2}$ State Institute of Genetic and Regenerative Medicine, NAMS of Ukraine \\ 67, Vyshhorodska Str., Kyiv, Ukraine, 04114 \\ yasnenka@gmail.com
}

\begin{abstract}
Aim. The development of a laboratory method for the production of immunoaffinity chromatography medium for the purification of the recombinant human IFN- $\beta 1 b$. Methods. A gene of the chimeric protein $\mathrm{ScFv}_{\mathrm{bINF}}-\mathrm{CBD}$ was constructed using the DNA sequences encoding ScFv specific to hIFN- $\beta 1 \mathrm{~b}$ and the cellulose-binding domain (CBD) of Clostridium thermocellum. The developed chimeric protein was expressed in Escherichia coli cells. The target protein was obtained in soluble, functionally active form by its renaturation from the bacterial inclusion bodies in vitro. The $\mathrm{ScFv}_{\mathrm{bINF}}-\mathrm{CBD}$ was immobilized on a chitin carrier. Results. The introduction of CBD by gene engineering techniques enabled the oriented non-covalent immobilization of $\mathrm{ScFv}_{\mathrm{bINF}}-\mathrm{CBD}$ on chromatographic matrix. The developed immunoaffinity medium allowed isolating the rhIFN- $\beta 1 \mathrm{~b}$ from the complex mixture, after its renaturation from the inclusion bodies, with more than $89 \%$ purity. Conclusion. The designed immunoaffinity medium provides isolating the rhIFN- $\beta 1 \mathrm{~b}$ from the complex protein mixtures.
\end{abstract}

Keyw or d s: Interferon- $\beta 1$ b, single-chain antibodies, immunoaffinity purification, cellulose-binding domain.

\section{Introduction}

The purification of a recombinant protein by immunoaffinity chromatography is based on the interaction of an antibody, which is covalently immobilized on the matrix, with its antigen that separates the latter from the multicomponent mixture. The main advantage of this method is a potentially high selectivity allowing the isolation of trace quantities of a target product from the mixture. However, the generation of antibodies in bulk quantities, for the development of such media, is a difficult and costly process that requires the maintenance of either the significant livestock of immunized animals or the hybrido- ma cell line, which produces the antibodies specific to the target antigen, and their further expression and purification. Special efforts also should be taken to the elaboration of the isolated antibody immobilization on the media, because the existing methods of covalent immobilization (by crosslinking reagents such as glutaraldehyde and etc.) are unable to provide the strictly oriented linkage of the antibody to the matrix, and hence a significant quantity of antibodies loses their antigen binding properties owing to the blocking or modification of the antigen binding site of antibody, and etc. due to the immobilization procedure. All facts mentioned above influence both the technical characteristics of media, and their

(C) 2015 Ia. Pokholenko et al:; Published by the Institute of Molecular Biology and Genetics, NAS of Ukraine on behalf of Biopolymers and Cell. This is an Open Access article distributed under the terms of the Creative Commons Attribution License (http://creativecommons.org/licenses/by/4.0/), which permits unrestricted reuse, distribution, and reproduction in any medium, provided the original work is properly cited 
cost. A technology of the recombinant single-chain antibodies $(\mathrm{ScFv})$, developed in the last decade, enables to simplify significantly the process and reduce the cost of obtaining antibodies. In addition, it is possible to introduce the DNA sequence for a protein, which will provide oriented immobilization of $\mathrm{ScFv}$ on a matrix, into the encoding sequence of the antibody by the genetic engineering techniques $[1,2]$.

The recombinant human interferon- $\beta 1 \mathrm{~b}$ (rhIFN$\beta 1 \mathrm{~b})$ is the first medicine approved for the treatment of multiple sclerosis (MS). MS is an autoimmune disease, which is characterized by the neurons demyelination in the central nervous system that leads to the development of a wide spectrum of severe neurological disorders [3]. Today, according to the data presented by Multiple Sclerosis International Federation [http://www.msif.org.], 2.3 million people worldwide have MS and the number of patients is continuously growing. The disease mainly affects young people: from 25 to 40 years old. The therapeutic effect of rhIFN- $\beta 1$ b on the disease is attributed to its anti-inflammatory properties, to the influence on the endothelial cells, and on the permeability of the blood brain barrier [4].

The present study is focused on the development of the laboratory method for the production of immunoaffinity chromatography medium for the purification of the rhIFN- $\beta 1 \mathrm{~b}$. The method is based on the oriented non-covalent immobilization of the chimeric protein, which consists of ScFv against rhIFN$\beta 1 \mathrm{~b}\left(\mathrm{ScFv}_{\mathrm{bINF}}\right)$ and Clostridium thermocellum cellulose-binding domain (CBD), on a chitin carrier.

\section{Materials and Methods}

$\mathrm{ScFv}$ against the rhIFN- $\beta 1 \mathrm{~b}$, obtained earlier at our department from the plasmid vector $p C A N T A B-5 E$ $S c F v-\beta 1 I N F$, was subcloned into the plasmid vector pET24-CBD-(Gly-spaser) via restriction sites SfiI and NotI. As a spacer for the spatial separation of two affinity centers of the chimeric protein (CBD and $\mathrm{ScFv}$ ) a sequence of 13 amino acids was introduced $[5,6]$. Professor Y. Shoham (Israel) kindly provided the plasmid vector $p C B D$ with the cellulose binding domain (CBD) sequence from Clostridium thermocellum for our research. The re- sulting plasmid $p E T-24-S c F v-C B D$ was used for the transformation of $E$. coli cells, BL21(DE3) strain.

For the expression of the target protein, an auto-induction method described by Studier [7] was applied. The localization and the content of the target protein in the total lysate of $E$. coli cells were determined by electrophoretic separation of the soluble and insoluble fractions of the cell cytoplasmic proteins [8]. E.coli cells were disrupted with lysozyme as described below [9]. The isolated inclusion bodies were solubilized in 20 $\mathrm{mM}$ Tris- $\mathrm{HCl}$ ( $\mathrm{pH} 8.0$ ), $7 \mathrm{M}$ guanidine- $\mathrm{HCl}, 15 \mathrm{mM}$ 2-mercaptoethanol for $1 \mathrm{~h}$ at room temperature and filtered through a $0.45 \mu \mathrm{m}$ PVDF membrane filter (Mi1lipore). $\mathrm{ScFv}_{\mathrm{bINF}}-\mathrm{CBD}$ was purified under denaturing conditions using the $\mathrm{Ni}^{2+}$-immobilized affinity chromatography on Ni-NTA agarose (Qiagen).

Refolding of the purified $\mathrm{ScFv}_{\mathrm{bINF}}-\mathrm{CBD}$ was performed by stepwise dilution [6]. After renaturation $\mathrm{ScFv}_{\text {bINF }}-\mathrm{CBD}$ was immobilized on chitin beads (New England Biolabs, UK). The resulting immunoaffinity medium was washed with PBS $\mathrm{pH} 7.2$, containing $0.1 \%$ Tween- 20 and $0.14 \mathrm{M} \mathrm{NaCl}$. Afterwards, the rhIFN-1 $\beta$ renatured by stepwise dilution was applied to the column [5]. After washing of the immunoaffinity medium with buffer PBS $\mathrm{pH} 7.2$, containing $0.1 \%$ Tween-20, $0.14 \mathrm{M} \mathrm{NaCl}$ to remove unbound proteins, the rhIFN- $\beta 1 \mathrm{~b}$ was eluted from the column by decreasing $\mathrm{pH}$ of elution buffer: ( $0.1 \mathrm{M}$ glycine and $0.5 \mathrm{M} \mathrm{NaCl}, \mathrm{pH} 3.0)$. The rhIFN- $\beta 1 \mathrm{~b}$ concentration in the fraction eluted was quantified by measuring $a b-$ sorbance of the solutions at $280 \mathrm{~nm}$. The rhIFN- $\beta 1 \mathrm{~b}$ purity in the samples studied was determined by densitometry of polyacrylamide gel electrophoregrams. For this purpose the SDS-PAGE gels were stained with Coomassie Brilliant Blue according to the manufacturers instructions, documented by ChemiDoc ${ }^{\mathrm{TM}}$ $\mathrm{XRS}+$ System («Bio- Rad», USA), and subsequently analyzed with «Image Lab SoftwareTM» («Bio$\operatorname{Rad} »)$.

\section{Results and Discussion}

1. Construction of chimeric protein and expression in E. coli BL21 (DE3)

The CBD from the S1 subunit of the cellulolytic 
complex of Clostridium thermocellum has been selected as a partner protein for the fusion with the previously developed $\mathrm{ScFv}$ against the rhIFN- $\beta 1 \mathrm{~b}[10]$. It is worth mentioning, that the main features of the domain are its ability to create a stable complex with the hydrocarbon backbone of cellulose or chitin under both native and denaturing conditions, and a high efficiency of the restoration of the molecule functional structure after the renaturation from inclusion bodies $[11,12]$. After the subcloning, the E.coli cells of the BL21(DE3) strain were transformed by the developed $p E T 24-S c F v_{b I N F}-C B D$. It is known that the components of the nutrient medium, the nature of inducer substance, and the cultivation conditions (temperature, aeration intensity, etc.), greatly influence the level of expression of the recombinant proteins in E.coli cells [13]. To enhance the yield of the chimeric protein $\mathrm{ScFv}_{\mathrm{bINF}}-\mathrm{CBD}$ we have tested the influence of the complex nutrient medium for producing strain BL21 (DE3)/pET 24-ScF $v_{b I N F}-C B D$ on the yield of the chimeric protein. Thus, the developed producing strain was cultivated on two different media, namely LB and 2xYT. The expression of $\mathrm{ScFv}_{\mathrm{bINF}}-\mathrm{CBD}$ was induced by the addition of $\alpha$-lactose. It was shown that the cultivation on the complex nutrient medium LB results in the synthesis of the target chimeric protein with the expected molecular weight of $45 \mathrm{kDa}$, while the yield of the chimeric protein after cultivation in $2 \mathrm{xYT}$ was scarce and hardly detectable. The accumulation of the target protein was $\sim 0.1 \mathrm{~g}$ out of $1 \mathrm{~L}$ of the bacterial cells suspension in case of the LB medium. The study on the distribution of the $\mathrm{ScFv}_{\mathrm{bINF}}-\mathrm{CBD}$ in $E$. coli cells demonstrated that it was accumulated in the inclusion bodies, which were subsequently isolated after the lysis of cells (Fig. 1.)

\section{Purification and renaturation}

The isolated inclusion bodies were solubilized in the buffer containing $7 \mathrm{M}$ guanidine hydrochloride and 0.015 M 2-mercaptoethanol. After solubilization the $\mathrm{ScFv}_{\mathrm{bINF}}-\mathrm{CBD}$ was purified by the metal ion affinity chromatography using the Ni-NTA agarose (Qiagen). The purity of the obtained target protein was $95 \%$ as determined by the densitometry of polyacrylamide

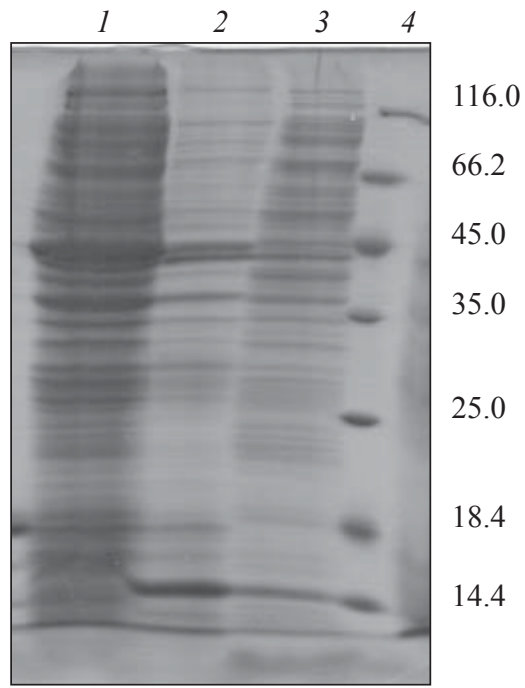

Fig. 1. Small-scale expression of the recombinant fusion protein ScFv-(IFN- $\beta$ )-CBD on LB. 1 - protein fractions from induced BL21(DE3) cells carrying the plasmid pET-24-(IFN- $\beta$ )-CBD; 2 - isolated inclusion bodies; 3 - cytoplasmic soluble fraction; 4 - molecular weight marker

gel electrophoregrams. The $\mathrm{ScFv}_{\mathrm{bINF}}-\mathrm{CBD}$ was renatured by step-wise dilution. The decrease of the concentration of guanidine hydrochloride was carried out by step-wise dilution of the protein solution with the renaturation buffer $20 \mathrm{mM}$ Tris- $\mathrm{HCl} \mathrm{pH} 8.0,100$ $\mathrm{mM} \mathrm{NaCl}, 1 \mathrm{mM}$ EDTA in order to provide the following concentration levels of the chaotropic agent: $6 \mathrm{M} \rightarrow 3 \mathrm{M} \rightarrow 2 \mathrm{M} \rightarrow 1 \mathrm{M} \rightarrow 0.5 \mathrm{M}$. At the concentrations of $2 \mathrm{M} \rightarrow 1 \mathrm{M} \rightarrow 0.5 \mathrm{M}$ the $0.4 \mathrm{M}$ L-arginine and the redox pair (GSH and GSSG) were added. The GSH/GSSG pair catalyzes the disulfide interchanges and thus ensures the correct folding of the chimeric protein and the proper spatial arrangement of both affinity sites: CBD and the active site of $\mathrm{ScFv}_{\text {bINF }}$. The renaturation efficiency of the affinity sites was evaluated in accordance with their functions: the ability of CBD to interact with the cellulose carrier and the ScFv ability to bind rhIFN- $\beta 1 b$.

\section{Immobilization of $S c F v_{b I N F}-C B D$ on chitin beads}

It has been demonstrated that the affinity interaction of CBD with the cellulose or chitin leads to the formation of the complex stabilized by the hydrophobic interaction of certain amino acid residues and hydrocarbon 


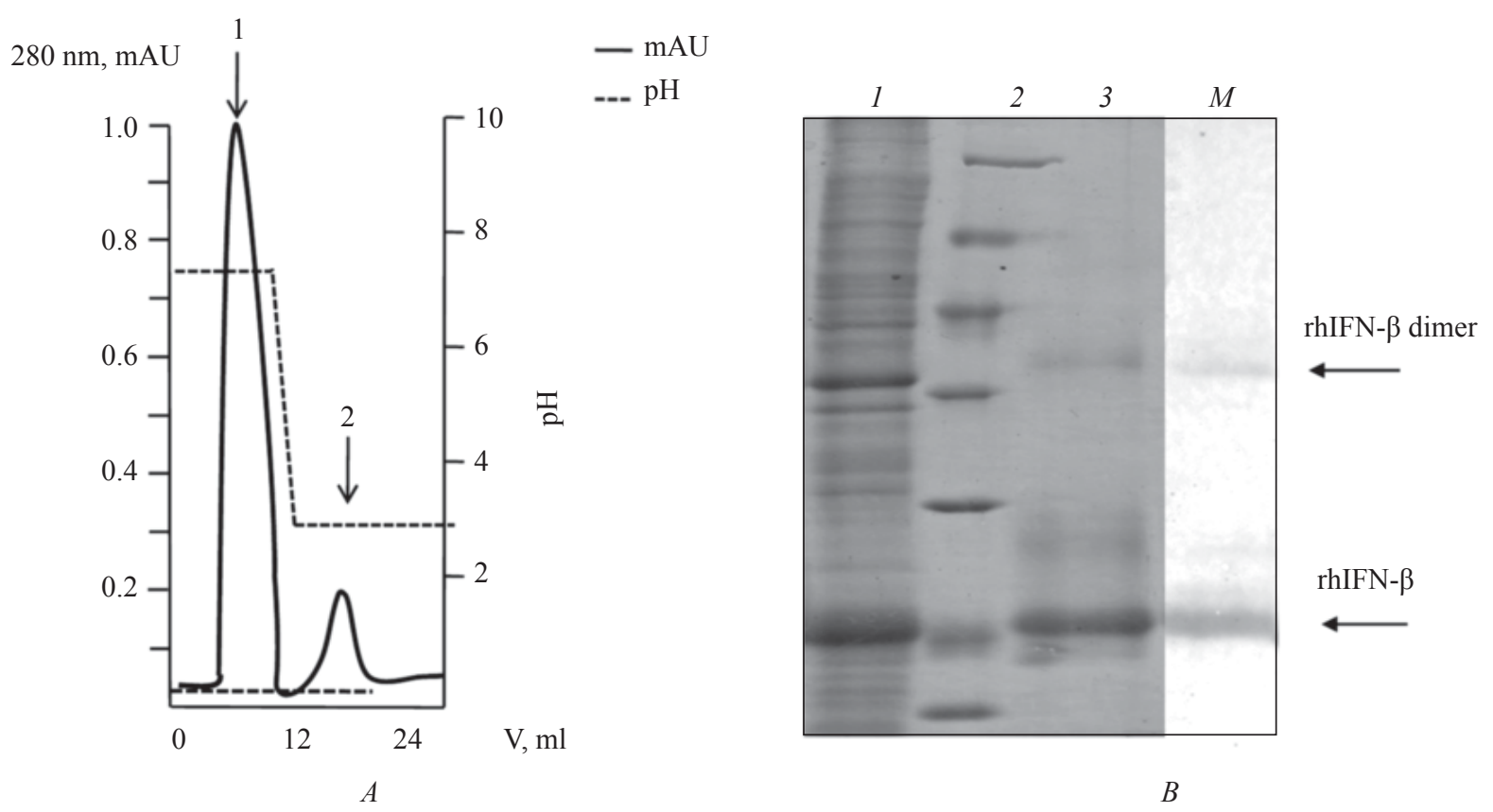

Fig. 2. Purification of rhIFN- $\beta$ on immunoaffinity medium. Chromatogram $(A)$ : 1 - non-bound proteins washed from the column with the buffer, $2-$ rhIFN- $\beta$ eluted from the column. Electrophoregram $(B)$ : 1-refolded rhIFN- $\beta$ applied to the column, $2-$ purified rhIFN- $\beta$ eluted from the column under acidic conditions, 3 - immunoblotting of purified rhIFN- $\beta$ with polyclonal anti-rhIFN- $\beta$ antibodies (Sigma), M - molecular weight marker top to bottom: 116.0, 62.0, 45.0, 35.0, 25.0, 18.4, 14.4 kDa)

backbone of the matrix [14]. The chitin beads have been selected as the solid phase for immobilization of the chimeric protein. The protein solution obtained after the renaturation procedure, was added to the slurry of chitin beads, equilibrated with buffer $0.1 \mathrm{M}$ Tris- $\mathrm{HCl}$ ( $\mathrm{pH}$ 8.0) containing $0.1 \mathrm{M} \mathrm{NaCl}$, and incubated with continuous agitation at $22^{\circ} \mathrm{C}$ for 2 hours. Thereafter the medium was packed in the column and washed by 5 volumes of PBS pH 7.2, in order to wash away the unbound proteins. The proteins attached to the chitin carrier were eluted under denaturing conditions and separated by SDS-PAGE. The analysis of electrophoregram revealed the presence of chimeric protein in eluate. The binding capacity of the chitin beads for the target protein was $\sim 0.6-1 \mathrm{mg}$ of the $\mathrm{ScFv}_{\mathrm{bINF}}-\mathrm{CBD} / \mathrm{mL}$ of the medium as determined by the densitometry of polyacrylamide gel electrophoregrams.

\section{Purification of rhIFN- $\beta 1 b$ on developed medium}

The solution of the rhIFN- $\beta 1 \mathrm{~b}$ (obtained after its re- naturation) containing a significant amount of E.coli proteins was applied of the column with developed affinity medium. The rhIFN- $\beta 1 \mathrm{~b}$ was eluted by the $\mathrm{pH}$ change: from $\mathrm{pH} 7.2$ to $\mathrm{pH} 3.0$. The analysis of electrophoregrams obtained after the separation of eluted proteins by SDS-PAGE (Fig. 2) revealed that the purity of the rhIFN- $\beta 1 \mathrm{~b}$, eluted under conditions studied, was $89 \%$, and the additional minor band was also detected. Desorption of the $\mathrm{ScFv}_{\text {ifnb }}-\mathrm{CBD}$ from the medium was not observed under the conditions studied. The data obtained by western-blot analysis (Fig. 2.b) revealed that the additional band with the molecular weight $\sim 36 \mathrm{kDa}$ represented the dimer of rhIFN- $\beta 1 \mathrm{~b}$, originated from its oligomerization during renaturation. It should be noted that the affinity media based on the use of antibodies do not allow separating the monomer from the oligomer forms of the same protein in case of the preservation of the epitope to which the antibody is specific. The final polishing of the eluate containing the rhIFN$\beta 1 \mathrm{~b}$ from its oligomer forms can be carried out by 
the fractionation of the protein mixture by a sizeexclusion chromatography on Superdex 75 10/300 GL column.

\section{Concluding Remarks}

The present study is focused on the development of the laboratory method for obtaining the immunoaffinity medium for the chromatographic purification of the rhIFN- $\beta 1 b$. The proposed method is based on the oriented non-covalent immobilization of the chimeric protein, consisting of the ScFv specific to the rhIFN- $\beta 1 \mathrm{~b}$ and the CBD from Clostridium thermocellum, on the chitin carrier. The developed immunoaffinity medium allows isolating the rhIFN- $\beta 1 \mathrm{~b}$ from the complex protein mixture after its renaturation from the inclusion bodies, and purification to $89 \%$. It is noteworthy that the developed media does not separate the oligomeric forms of rhIFN- $\beta 1 \mathrm{~b}$, appeared during the renaturation.

\section{Acknowledgements}

The authors thank Professor Y. Shoham, Dr. M. Pavlova, and Dr. P. Gilchuk for their valuable assistance in the publication of the current work.

\section{Funding}

This work was partially supplied by the grant «Developing a fundamental basis for obtaining immunoreagents of new generation».

\section{REFERENCES}

1. Blank K, Lindner P, Diefenbach B, Plückthun A. Self-immobilizing recombinant antibody fragments for immunoaffinity chromatography: generic, parallel, and scalable protein purification. Protein Expr Purif. 2002;24(2):313-22.

2. Berry MJ, Davies J, Smith CG, Smith I. Immobilization of Fv antibody fragments on porous silica and their utility in affinity chromatography. J Chromatogr. 1991;587(2):161-9.

3. Compston A, Coles A. Multiple sclerosis. Lancet. 2008;372 (9648):1502-17.

4. Minagar A. Current and future therapies for multiple sclerosis. Scientifica (Cairo). 2013;2013:249101.

5. Pavlova MV, Nikolaev IuS, Irodov DM, Okunev OV, Kordium $V A$, Gil'chuk $P V$. [Characterization of a panel of mouse single-chain antibodies against recombinant human interferon beta1b]. Tsitol Genet. 2008;42(4):3-11.

6. Gilchuk PV, Okunev OV, Irodov DM, Pavlova MV, Yakovenko $O Y a$. Immobilized single chain antibodies for affinity purifi- cation of recombinant human IFN- $\alpha 2$ b. Biopolym Cell. 2006; 22(2):157-61.

7. Studier FW. Protein production by auto-induction in high density shaking cultures. Protein Expr Purif. 2005;41(1): 207-34.

8. The Protein Protocols Handbook. Ed. Walker JM. Humana Press Inc. 20091984 p.

9. Sambrook J, Fritsch EF, Maniatis T. Molecular cloning: A laboratory manual. New York: Cold Spring Harbor Lab. press, 1989.

10. Morag E, Lapidot A, Govorko D, Lamed R, Wilchek M, Bayer EA, Shoham $Y$. Expression, purification, and characterization of the cellulose-binding domain of the scaffoldin subunit from the cellulosome of Clostridium thermocellum. Appl Environ Microbiol. 1995;61(5):1980-6.

11. Bayer EA, Morag E, Lamed R. The cellulosome - a treasure-trove for biotechnology. Trends Biotechnol. 1994;12 (9): 379-86.

12. LehtiöJ, Sugiyama J, Gustavsson M, Fransson L, Linder M, Teeri TT. The binding specificity and affinity determinants of family 1 and family 3 cellulose binding modules. Proc Natl Acad Sci U S A. 2003;100(2):484-9.

13. Guo JQ, You SY, Li L, Zhang YZ, Huang JN, Zhang CY. Construction and high-level expression of a single-chain Fv antibody fragment specific for acidic isoferritin in Escherichia coli. J Biotechnol. 2003;102(2):177-89.

14. Tormo J, Lamed R, Chirino AJ, Morag E, Bayer EA, Shoham $Y$, Steitz TA. Crystal structure of a bacterial family-III cellulose-binding domain: a general mechanism for attachment to cellulose. EMBO J. 1996;15(21):5739-51.

\section{Створення хроматографічного сорбенту на основі іммобілізованих одноланцюгових антитіл для афінного виділення рекомбінантного IFN-ק1b людини}

Я. О. Похоленко, О. Б. Горбатюк, О. В. Окунєв, Д. М. Іродов, М. І. Дегтярьова, О. Г. Паливода, В. А. Кордюм

Мета. Розробити лабораторний метод створення імуноафінного хроматографічного сорбенту для виділення та очищення рекомбінантного IFN- $\beta 1 \mathrm{~b}$ людини. Методи. Використовуючи послідовності ДНК, які кодують $\mathrm{ScFv}$ специфічні до hIFN- $\beta 1 \mathrm{~b}$, та целюлозозв'язувальний домен (CBD) Clostridium thermocellum, створено ген химерного протеїну $\mathrm{ScFv}_{\mathrm{bINF}^{-}}$ $\mathrm{CBD}$. Проведено експресію створеного химерного протеїну в клітинах Escherichia coli. Цільовий білок одержували у розчинній, функціонально активній формі шляхом ренатурації з бактеріальних тілець включення in vitro. $\mathrm{ScFv}_{\mathrm{bINF}}{ }^{-}$ CBD іммобілізували на хітиновому носії. Результати. Введення CBD до складу химерного білка забезпечує орієнтовану, не ковалентну іммобілізацію $\mathrm{ScFv}_{\mathrm{bINF}}-\mathrm{CBD}$ на хроматографічній матриці. За допомогою створеного імуноафінного 
сорбенту було виділено rhIFN- $\beta 1 \mathrm{~b}$ зі складної суміші білків, одержаної після його ренатурації з тілець включення, з чистотою більше ніж 89 \%. Висновки. Створений імуноафінний хроматографічний сорбент дозволяє виділяти рекомбінантний IFN- $\beta 1 \mathrm{~b}$ людини зі складних сумішей білків.

Кл юч о в і с л о в а: інтерферон- $\beta 1 \mathrm{~b}$, одноланцюгові антитіла, імуноафінне очищення, целюлозозв'язувальний домен.

\section{Создание хроматографического сорбента основанного на иммобилизированных одноцепочечных антителах для аффинного выделения рекомбинантного IFN-ß1b человека}

Я. А. Похоленко, О. Б. Горбатюк,

О. В. Окунев, Д. М. Иродов, М. И. Дегтярева,

О. Г. Паливода, В. А. Кордюм

Цель. Разработать лабораторный метод создания иммуноаффинного хроматографического сорбента для выделения и очистки рекомбинантного IFN- $\beta 1 \mathrm{~b}$ человека. Методы. Используя последовательности ДНК, кодирующие ScFv спе- цифичные к hIFN- $\beta 1 \mathrm{~b}$, и целлюлозосвязывающий домен (CBD) Clostridium thermocellum, создан ген химерного белка $\mathrm{ScFv}_{\mathrm{bINF}}$-CBD. Проведена экспрессия созданного химерного белка в клетках Escherichia coli. Целевой белок получали в растворимой, функционально активной форме путем ренатурации из бактериальных телец включения in vitro. $\mathrm{ScFv}_{\mathrm{bINF}}-\mathrm{CBD}$ иммобилизовали на хитиновом носителе. Результаты. Введение CBD в состав химерного белка обеспечивает ориентированную не ковалентную иммобилизацию $\mathrm{ScFv}_{\mathrm{bINF}}-\mathrm{CBD}$ на хроматографической матрице. $\mathrm{C}$ помощью созданного иммуносорбента был выделен rhIFN$\beta 1 \mathrm{~b}$ из сложной смеси белков, полученной после его ренатурации из телец включения, с чистотой более 89 \%. Выводы. Созданный иммуноаффинный хроматографический сорбент позволяет выделять рекомбинатный IFN- $\beta 1 \mathrm{~b}$ человека из сложных белковых смесей.

Кл юч е в ы е с л о в а: интерферон- $\beta 1$ b, одноцепочечные антитела, иммуноаффинная очистка, целлюлозосвязывающий домен.

Received 01.05.2015 